
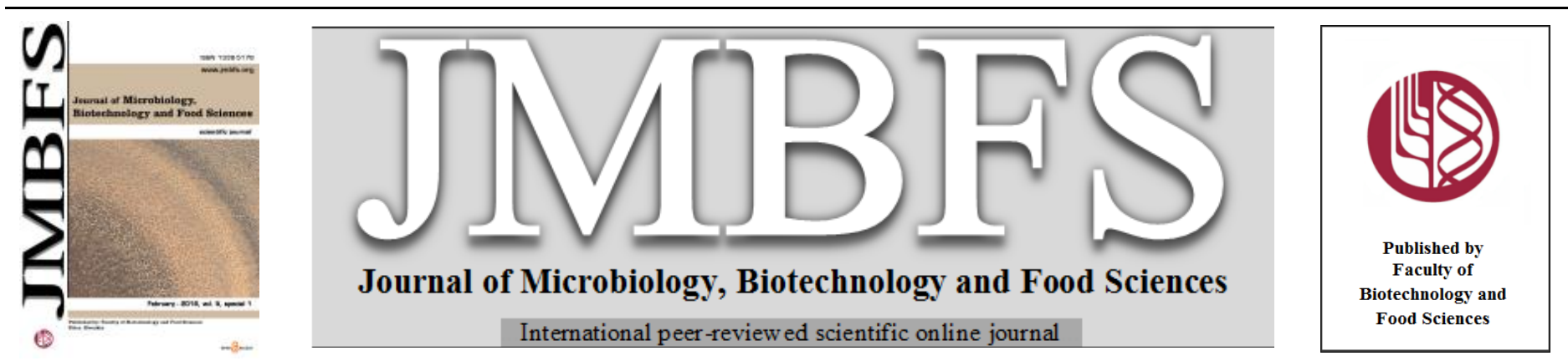

\title{
DETERMINATION OF NITRATE AS A SOURCE OF RISK FOR HUMAN IN GROUNDWATERS
}

\author{
Peter Lazor* ${ }^{I}$, Terézia Mad'aričová ${ }^{2}$ Tomáš Tóth ${ }^{1}$, Ján Tomáśl , Martin Šimko
}

Address(es): doc. Mgr. Ing. Peter Lazor, PhD.,

${ }^{1}$ Slovak University of Agriculture in Nitra, Faculty of Biotechnology and Food Sciences, Department of Chemistry, Tr. A. Hlinku 2, 94976 Nitra, Slovakia, phone number: +4213764345.

${ }^{2}$ The National Institute of Cardiovascular Diseases, Department of Cardiovascular Medicine, Pod Krásnou hôrkou 1, 83348 Bratislava III, Slovakia, phone number: +421259320111.

*Corresponding author: Peter.Lazor@uniag.sk

doi: 10.15414/jmbfs.2016.5.special1.4-6

\section{ARTICLE INFO}

Received 29. 12. 2015

Revised 13.1. 2016

Accepted 20.1.2016

Published 8. 2. 2016

Regular article

OPEN $\partial_{\text {ACCESS }}$

\begin{abstract}
We monitored the content of nitrates $\left(\mathrm{NO}_{3}^{-}\right)$in samples taken from individual groundwater resources in the cadastral territory of the city of Nitra and Zobor (Svorad's spring, spring Šindolka and spring Buganka), also used for human consumption in the period $2012-2014$. $\mathrm{NO}_{3}{ }^{-}$contents were assessed by Photocolorimetric method. We also evaluated the results achieved in relation to the current legislation in this area.

The results of the performed analyzes throughout the period shows that the average concentration of $\mathrm{NO}_{3}{ }^{-}$represented in the samples of water from Svorad's spring was $12,6 \mathrm{mg} . \mathrm{dm}^{-3}$, spring Šindolka $38,0 \mathrm{mg} \cdot \mathrm{dm}^{-3}$ and spring Buganka $103,1 \mathrm{mg} . \mathrm{dm}^{-3}$

The nitrate concentration did not exceed the limit value in samples from spring Sindolka and spring Svorad. Spring Buganka had this value exceeded by up to $100 \%$ of cases. We do not recommend to use water for human consumption from spring Buganka based on the measured values.
\end{abstract}

Keywords: Groundwater, quality, nitrates, city of Nitra

\section{INTRODUCTION}

The origin, evolution and physical - chemical characteristic of the water cover of Earth - hydrosphere is closely linked with the development of its other parts. Between the earth's mantle and the earth's crust, the hydrosphere, atmosphere, lithosphere and biomass occurs constant exchange of water (Wen Ling, Saintilan, Rogers, 2009), that causes changes its chemical and isotopic composition (Harris, Hobbs, Higgs, 2006). This is called hydrological cycle, which represents a stable water cycle on Earth.

An indispensable part of the hydrological cycle and a key element in maintaining wetlands and flows in rivers during dry periods is groundwater. It is the part of subsurface water, which forms a continuous level in the ground and the part that fills the cavity of water-bearing rock irrespective of whether it generates or does not generate continuous level (Bekes, Moiler, 2009). According to the mineralization (total dissolved solids) and gas content are divided groundwaters to normal and mineral.

Processes determining qualitative and quantitative composition of natural waters are the nature of the physical, chemical and biochemical (Gemitzi, Stefanopoulos, 2011). Furthermore, the nature of natural waters are also affected by climatic conditions, the overall landscape, density and nature of the settlement and so on. (Turnbull, Jin, Clancy, 2007).

We use groundwaters for drinks water in our area. It is representing almost 82,2 $\%$. Drinking water supply is used only from underground water sources in the Nitra region. The town of Nitra is supplied from Ponitrianske group water supply and group water supply of Jelka - Galanta - Nitra. On the legislative front, the requirements for water quality is defined by law no. 355/2007 Coll. on protection, support and development of public health and amending certain laws as amended and Government Regulation No.. 354/2006 Coll., Laying down requirements on water intended for human consumption and quality control of water intended for human consumption as amended by Government Regulation no. 496/2010 Coll..

It is generally believed that the content of $\mathrm{NO}_{3}^{-}$in the groundwater in the environmental conditions controlled by activities of microorganisms, i.e., mainly the nitrification and denitrification processes. Precipitation water have nitrate concentrations low in Slovakia, averaging 2,65 mg.dm ${ }^{-3}$ (Bodiš et al., 2000). $\mathrm{NO}_{3}{ }^{-}$concentration is usually increasing in soil water, mainly as a result of biochemical transformations ammonium $\left(\mathrm{NH}_{4}{ }^{+}\right)$present in the source (mainly rainfall) water.
Nitrates are in the human body after oral intake rapidly and completely absorbed in the upper small intestine and rapidly distributed in the body. About $25 \%$ is excreted into the saliva, which is partially reduced to nitrite by oral microflora. Bacterial nitrate reduction $\left(\mathrm{NO}_{3}^{-}\right)$to nitrite $\left(\mathrm{NO}_{2}^{-}\right)$may be configured in other parts of the digestive tract other than the stomach, where it occurs only at a reduced $\mathrm{pH}$ (Abern, Wise, Wright, 2004) by the equation:

$$
\mathrm{NO}_{3}^{-} \rightarrow \mathrm{NO}_{2}^{-} \rightarrow \mathrm{H}_{2} \mathrm{~N}_{2} \mathrm{O}_{2} \rightarrow \mathrm{NH}_{2} \mathrm{OH} \rightarrow \mathrm{NH}_{3} \rightarrow \mathrm{NH}_{2}^{-}
$$

\section{MATERIAL AND METHODS}

Due to the fact that there are currently no available literature and data sources with a specific analytical outputs to the population in terms of quality ground water resources in the city of Nitra, we mentioned the issues addressed in our work. Aim of this study therefore was to obtain knowledge about the long-term quality of selected groundwater resources used for human consumption and for drinking purposes in the cadastral area of the city Nitra and Zobor, in terms of nitrate levels in the period 2012 - 2014 with the evaluation of their potential risk to the population. As a source of groundwater were evaluated:

1. Svorad's spring ( $\varphi=48020$ '47 ", $\lambda=18005$ '27 "), located in the woods, on a hiking trail Zobor and Svorad's cave under the hill of Zobor (586.9 $\mathrm{m}$ asl). It is situated at the highest altitude ( $305 \mathrm{~m}$ asl) from all sources in the cadastral area Zobor. It is a tourist places frequently visited throughout the year.

2. Spring Šindolka ( $\varphi=48019^{\prime} 50 ", \lambda=18005^{\prime} 00$ '), is situated on Orava street in Nitra. From the assessment of groundwater resources is at the lowest altitude of $158 \mathrm{~m}$ above sea level This spring is a significant of power flow throughout the year. People often use this water to irrigate their crops and also for direct consumption. In the surrounding area of the spring there are several potential polluters (Secondary school for agriculture, road, proximity to agricultural use of land and gardens).

3. Spring Buganka $(\varphi=48019 ' 50$ ", $\lambda=18006$ '04 '), located on Panská dolina street close to the restaurant. It is located on private land at an altitude of $214 \mathrm{~m}$ above sea level, but access to it is enabled. Water quality is threatened mainly fertilization and used in the surrounding garden and transportation. 
We took water samples intended for chemical analysis into polyethylene sample containers of $500 \mathrm{~cm}^{3}$, which we first rinsed with water and then filled up to the cap. The total nitrate content were assessed by Photocolorimetric method using UV mini 1240 PL

\section{RESULTS AND DISCUSSION}

We collected and defined the content of nitrate $\left(\mathrm{NO}_{3}{ }^{-}\right)$in groundwater samples from their individual sources monthly in the period 2012 - 2014. The results were processed in Table 1 which shows that:

Chart 1 Concentration of $\mathrm{NO}_{3}^{-}\left(\mathrm{mg} \cdot \mathrm{dm}^{-3}\right)$ in the period $2012-2014$ in water spring

\begin{tabular}{|c|c|c|c|c|c|c|c|c|c|c|c|c|c|}
\hline \multirow{2}{*}{ WS } & \multirow{2}{*}{ OP } & \multicolumn{12}{|c|}{ Year/month } \\
\hline & & I & II & III & IV & $\mathbf{V}$ & VI & VII & VIII & IX & $\mathbf{X}$ & XI & XII \\
\hline \multirow{3}{*}{ SS } & 2012 & 15,8 & 14,0 & 13,1 & 14,7 & 12,3 & 12,3 & 12,0 & 12,7 & 13,2 & 12,8 & 12,7 & 13,4 \\
\hline & 2013 & 11,3 & 8,4 & 6,7 & 8,1 & 11,6 & 12,7 & 15,8 & 13,1 & 11,2 & 10,9 & 9,7 & 11,7 \\
\hline & 2014 & 16,2 & 10,4 & 12,1 & 16,3 & 14,8 & 15,6 & 14,8 & 16,1 & 14,2 & 11,0 & 10,9 & 12,3 \\
\hline \multirow{3}{*}{ ŠS } & 2012 & 41,4 & 33,5 & 40,2 & 41,3 & 38,2 & 39,8 & 36,7 & 37,1 & 39,1 & 39,6 & 38,9 & 43,6 \\
\hline & 2013 & 35,1 & 37,4 & 42,3 & 39,4 & 41,2 & 44,3 & 42,1 & 39,9 & 36,4 & 38,5 & 41,5 & 40,4 \\
\hline & 2014 & 39,2 & 36,8 & 44,4 & 35,7 & 24,3 & 28,6 & 31,1 & 25,6 & 41,2 & 35,9 & 29,5 & 44,2 \\
\hline \multirow{3}{*}{ BS } & 2012 & 146,3 & 124,4 & 119,6 & 110,1 & 122,4 & 135,3 & 139,2 & 128,2 & 126,1 & 111,6 & 98,9 & 128,8 \\
\hline & 2013 & 95,8 & 89,6 & 85,4 & 80,1 & 71,9 & 69,1 & 73,2 & 71,9 & 72,4 & 83,4 & 79,4 & 76,5 \\
\hline & 2014 & 135,8 & 111,8 & 98,5 & 110,3 & 103,5 & 89,6 & 110,8 & 98,7 & 115,2 & 96,3 & 88,9 & 116,1 \\
\hline
\end{tabular}

Legend: WS - water spring, OP - Obset parameter, SS - Svorad spring, ŠS - Šindolka spring, BS - Buganka spring

The measured values of nitrate in Svorad's spring were ranged from 12,0 mg.dm 3 (July) to $15,8 \mathrm{mg} \cdot \mathrm{dm}^{-3}$ (January) during 2012. According to the literature, the toxic effects (particularly in children) depend mainly on the reduction of the nitrite and the subsequent reaction of nitrite with hemoglobin. Nitrate of occurrence of foodborne methemoglobinemia and oxidation of $\mathrm{Fe}^{2+}$ to $\mathrm{Fe}^{3+}$ in the conversion of hemoglobin $(\mathrm{Hb})$ to a dark brown methemoglobin (MetHb), which is unable to transport oxygen (Savino, Maccario, Guidi, 2006).

We found the minimum content of nitrates $6,7 \mathrm{mg} \cdot \mathrm{dm}^{-3}$ (March) up to a maximum of $15,8 \mathrm{mg} . \mathrm{dm}^{-3}$ (July) in 2013. We had the lowest value recorded in February $\left(10,4 \mathrm{mg} \cdot \mathrm{dm}^{-3}\right)$, while the maximum in April - $16,3 \mathrm{mg} \cdot \mathrm{dm}^{-3} \mathrm{NO}_{3}{ }^{-}$in 2014.

According to the authors (Erkekoglu, Baydar, 2009), to give the nitrate of alimentary methemoglobinemia apply particular factors, such as water with an inadmissible amount of nitrate, the $\mathrm{pH}$ of gastric juice, bacterial flora of the uppe GIT reducing nitrates, the absorption of nitrate from the gastrointestinal tract into the blood, influence enzyme system reducing methemoglobin to hemoglobin and possible influence of fetal hemoglobin.

Set the average nitrate content found throughout the period 2012 amounted in samples of Svorad's spring 13,2 mg.dm ${ }^{-3}$, in $2013-10,9 \mathrm{mg} \cdot \mathrm{dm}^{-3}$, during the yea 2014 - $13,7 \mathrm{mg}_{\mathrm{dm}}{ }^{-3}$. A source with the lowest $\mathrm{NO}_{3}{ }^{-}$content of all monitored sources. To consider for the future is worth to compare also spreading rate (flow) spring and other physical indicators, respectively. meteorological variables (the amount of atmospheric precipitation) that may be related to the issue.

We found a minimum content of $\mathrm{NO}_{3}^{-}$in water samples from spring Sindolka in February $\left(33,5 \mathrm{mg} . \mathrm{dm}^{-3}\right)$ to $43,6 \mathrm{mg} \cdot \mathrm{dm}^{-3}$ in December 2012. The found content of nitrate ranged from a minimum value of $35,1 \mathrm{mg} \cdot \mathrm{dm}^{-3}$ (January) to 44,3 mg.dm ${ }^{-3}$ (June) in 2013. The results obtained can be seen that in comparison with the previous assessment of groundwater resources (Svoradov spring) are about twice as high. Clearly, though, the greatest impact on the chemical composition and content of nitrate in groundwater are diffuse sources of pollution, which determine their varying degree of anthropogenic influence (Bodiš et al., 2000) Manifestation of these effects can be multiple increase of nitrate levels compared to background levels.

The measured concentrations ranged from a minimum of $24,3 \mathrm{mg} \cdot \mathrm{dm}^{-3}$ (April) up to the maximum established in March $\left(44,4 \mathrm{mg}^{-\mathrm{dm}^{-3}} \mathrm{NO}_{3}^{-}\right)$in 2014 ,. Such concentrations are a result of increased agricultural activity or arise nitrification activity of the bacteria. Important role in fluctuations in the concentration of $\mathrm{NO}_{3}$ have on the other hand also seasonal changes in temperature, which in practice excludes biochemical reactions in the winter.

We know from the literature (Šindelářová, 1985) that in the plants accumulate in higher concentrations when the plants can not use nitrogen. The cause can be improper temperature, humidity and especially the light conditions. An example can be greenhouse spring vegetables, containing up to several fold higher level of nitrates as a field or garden vegetables (Valašíková, 2005).

Nitrates in low concentrations and in non-reducing environment are not for a healthy adult harmful and therefore we can not talk about their primary toxicity.
It is associated with their relatively rapid liquidation of the kidney. It is known that up to 12 hours the kidneys excreted about $80 \%$ of the nitrate in middle population and about $50 \%$ in the elderly (Erkekoglu, Baydar, 2009). For the permissible daily doses or with prolonged intake does not cause any disturbance to health, is the FAO / WHO established a daily amount of nitrate equivalent to 5 $\mathrm{mg} \mathrm{NaNO}_{3}$ per $1 \mathrm{~kg}$ of body weight (FAO / WHO, 1985).

The average nitrate content found in 2012 and 2013 were in water samples from the source spring Šindolka more or less balanced by a concentration. It represented 39,1 mg.dm ${ }^{-3}$ in 2012. It was $39,9 \mathrm{mg} \cdot \mathrm{dm}^{-3}$ in 2013 and a slight decrease to $34,7 \mathrm{mg} . \mathrm{dm}^{-3}$ during the period of 2014 .

The minimum measured content of nitrates was in October $\left(98,9 \mathrm{mg} . \mathrm{dm}^{-3}\right)$ to a maximum of $146,3 \mathrm{mg} \cdot \mathrm{dm}^{-3}$ in January and December in samples taken from spring Buganka during the year 2012. These high concentrations of nitrates, which reduce to nitrites, excluding formation of methemoglobinemia, may cause the reaction of the secondary and tertiary amines which are present in virtually everywhere (vegetables, meat, milk and cereal products, eggs, beer, wine, medicines, pesticides, etc.) the formation of nitrosamines (Muro, Stucki, Roback, 2005)

The content ranged from $69,1 \mathrm{mg} \cdot \mathrm{dm}^{-3}$ in June to $95,8 \mathrm{mg}^{-\mathrm{dm}^{-3}}$ (January, February) in the evaluated year 2013. It was found that nitrosamines are able to induce tumor formation in all organs of the body, particularly the gastrointestina tract, urinary bladder and lymphatic system except bones. Regular intake of vitamin $\mathrm{C}$ can be prevented form carcinogenic nitrosamines, and on the other hand, chronically low levels of L-ascorbic acid may increase the disposition (EFSA, 2010).

We had a maximum nitrate levels $-135,8 \mathrm{mg} \cdot \mathrm{dm}^{-3}$ measured in January and the minimum - 88,9 mg.dm ${ }^{-3}$ in October in the last year of assessment (in 2014). It can be stated that in terms of toxicological and health assessment is a specific risk group population of children in connection with such detected high levels of $\mathrm{NO}_{3}$ in the samples.

Set average nitrate levels observed throughout the period 2012 amounted in samples of spring Buganka 124,2 mg.dm ${ }^{-3}$, in $2013-79,1 \mathrm{mg}^{-\mathrm{dm}^{-3}}$, during the year 2014 - 106,3 mg.dm ${ }^{-3}$.

The legal framework laying down the requirements for water quality and its control form the content of the Act No.126 / 2006 Coll. on public health and on amendments to certain laws and Government Regulation no. 354/2006 Coll., Laying down requirements on water intended for human consumption and quality control of water intended for human consumption.

Comparing the measured results of the average nitrate content with curren legislation, which provides drinking water of the highest limit of $50 \mathrm{mg} . \mathrm{dm}^{-3}$ on the basis of indirect toxic effects of nitrates on the human body establishes that the limit in samples of water from Svorad's spring and spring Šindolka are not exceeded. However, it was exceeded in samples of water from spring Buganka in 2012 by an average of $74,2 \mathrm{mg} \cdot \mathrm{dm}^{-3}$, about $29,1 \mathrm{mg} \cdot \mathrm{dm}^{-3}$ in 2013 and by 56,3 mg. $\mathrm{dm}^{-3}$ of $\mathrm{NO}_{3}{ }^{-}$in 2014. If we try to show illustratively also exceeding the limit value for nitrate in at least one year we find that, for example in 2014 (when we 
recorded the highest average, that exceedance), the maximum deviation was recorded in January and July, and on the other hand, the minimum in April and November as documented in chart 1 .

Chart 1 Exceeding the maximum limit on the $\mathrm{NO}_{3}{ }^{-}$in water from spring Buganka in 2014

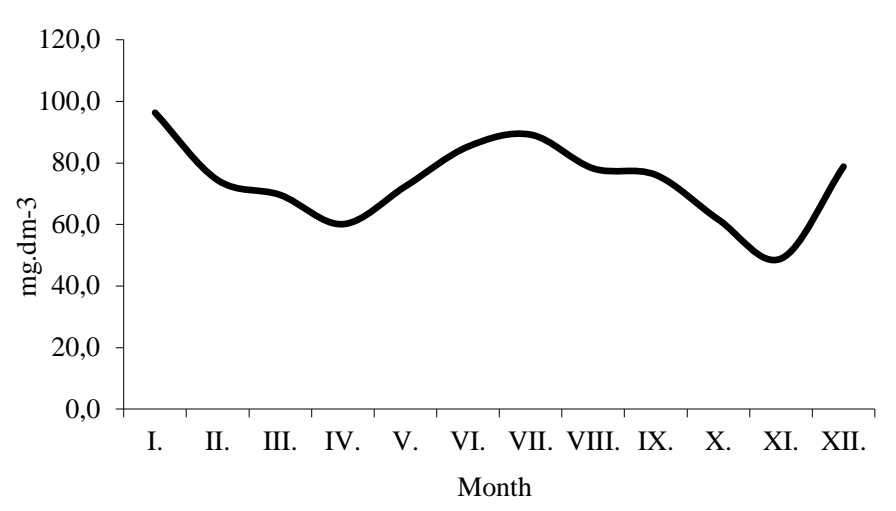

Mentioned could be due mainly by the position of spring in relation to fertilization used in the surrounding garden and seductive depth of the collector source. Therefore, the use of water for human consumption from the spring Buganka in terms of the nitrate content is not recommended for drinking.

\section{CONCLUSION}

We were assessed the content of nitrates $\left(\mathrm{NO}_{3}{ }^{-}\right)$in water samples taken from groundwater resources in the administrative territory of the town Nitra and Zobor, which are still used for human consumption. We obtained from the 108 experimental results that:

The total content of nitrates which got into the ground water impact the environmental pollution, agricultural activity or arise nitrification activity of the bacteria ranged on average throughout the period in samples from Svorad's spring from 10,9 to $13,7 \mathrm{mg} \mathrm{dm}^{-3}$, from the spring Šindolka from 39,1 to $39,9 \mathrm{mg}^{-\mathrm{dm}^{-3}}$ and spring Buganka from 79,1 to $124,2 \mathrm{mg}^{-\mathrm{dm}^{-3}}$.

Absorption of nitrate $\left(\mathrm{NO}_{3}{ }^{-}\right)$in the human body occurs in the upper small intestine. They are rapidly distributed in the body and then reduced to nitrite $\left(\mathrm{NO}_{2}{ }^{-}\right)$, which are substantially toxicologically dangerous as they react with the hemoglobin and the formation occurs of nitrate alimentary methemoglobinemia. Besides formation of methemoglobinemia the reduced nitrites by reacting with secondary and tertiary amines, which are present almost everywhere (vegetables, meat, milk, cereal products, eggs, and a.) creation of risk nitrosamines.

When comparing the measurement results with current legislation in the given field and the highest limit value nitrate content in water intended for human consumption, we found that the limit was exceeded in samples taken from spring Buganka, a total of 36 times throughout the period 2012-2014.

Samples of water from the spring Buganka it was on average up to $74,2 \mathrm{mg} \cdot \mathrm{dm}^{-3}$ in 2012. This value was exceeded in samples of spring Buganka $29,1 \mathrm{mg} . \mathrm{dm}^{-3}$ in the period 2013 and by $56,3 \mathrm{mg} . \mathrm{dm}^{-3}$ of $\mathrm{NO}_{3}^{-}$in 2014 .

Based on this fact in terms of establishing the overall average of the nitrate content, groundwater from a given spring Buganka that has failed in the high limit value in this parameter for drinking purposes is not recommended.

Acknowledgments: This work was supported by the project projekt VEGA $1 / 0456 / 12$

\section{REFERENCES}

BERESFORD, S. 1995. Is nitrate in the drinking water associated with the risk of cancer in the urban U.K. International Journal of Epidemiology. 14(1). 57-63. http://dx.doi.org/10.1093/ije/14.1.57

BODIŠ, D. 2010: Pozad’ová koncentrácia vybraných ukazovatel'ov v povrchovej a podzemnej vody Slovenska. Štátny geologický ústav Dionýza Štúra : Bratislava, 2010. ISBN 978-80 89343-43-0.

BODIŠ, D., LOPAŠOVSKÁ, M., LOPAŠOVSKÝ, K. 2000. Chemické zloženie snehovej pokrývky na Slovensku - výsledky 25-ročného pozorovania. Podzemná voda č.2, X. Slovenská hydrogeologická konferencia, Herl'any. 162-173.

BOUCHARD, A. 2009. Nitrate contamination of groundwater: sources and potential health effects. 150 p. ISSN 1992-6197

DARRACQ, M., DAUBERT, G. 2007. Cyanotic toddler. Pediatric Emergency Care, 2007; 23(3):195-199. http://dx.doi.org/10.1097/pec.0b013e3180330a2c

EFSA. 2010. Panel on Contaminants in the Food Chain (CONTAM). Statement on possible public health risks for infants and young children from the presence of nitrates in leafy vegetables. EFSA Journal, 2010; 12(1935):1-42.
ERKEKOGLU, P., BAYDAR, T. 2009. Evaluation of nitrite contamination in baby foods and infant formulas marketed in Turkey. International Journal of Food Sciences and Nutrition, 2009; 60(3):206-209. http://dx.doi.org/10.1080/09637480701690311

FAO/WHO. 1985. Food Additives Data Systems. Evaluations by the Joint FAO/WHO Expert Committee on Food Additives 1956-1984 FAO. Food and Nutrition Paper 30/Rev Rome, 1985. 115 s.

KOŽIŠEK, F. 2007. Je vodovodni voda vhodna pro připravu kojenecke stravy? Praktický lékař 2007; 87(4):224-227.

KRATOCHVÍL， J, MARTINKOVÁ, V., MASOPUST, J. 2010. Methemoglobinemie. Urgentni medicina 2010; 13 (2): 33 - 34

KRČ, R., IVANOVÁ, L', KRIŽANOVÁ, H., 2007. Grafické zobrazenie časových zmien vybraných ukazovatel'ov kvality povrchových vôd v Slovenskej republike. Správa. SHMÚ, Bratislava, 2007. $125 \mathrm{~s}$.

LANZ, K. 2001. Príručka: European Environment Bureau (EEB) o vodohospodárskej politike EÚ podl'a Rámcovej smernice o vodách. Bratislava : REC pre krajiny strednej a východnej Európy, 2001. $53 \mathrm{~s}$.

MIKE, E., SHAND, P. 2011. Natural Groundwater Quality. 488 p. ISBN: 978-14051-5675-2.

MURONE, A, STUCKI, P., ROBACK, M. 2005. Severe Methemoglobinemia due to food intoxication in infants. Pediatric Emergency Care 2005; 21(8):536538. http://dx.doi.org/10.1097/01.pec.0000175452.15793.7e

MŽP SR. 2012. Charakteristika verejných vodovodov podla akciových spoločností. MŽP SR : 2012. $124 \mathrm{~s}$.

PADO, R. 2001. Kvalita povrchových vôd na Slovensku 1999-2000. Bratislava : SHMÚ. 2001. $490 \mathrm{~s}$

PIZINGEROVA, K., FREMUTH, J., ŠAŠEK, L. 2011. Akutni methemoglobinemie - zavažna alimentarni intoxikace zeleninou koupenou na trhu. Pediatra pre prax, $2011 ; 12(5): 216-219$.

SAVINO, F., MACCARIO, S., GUIDI, C. 2006. Methemoglobinemia Caused by the Ingestion of Courgette Soup Given in Order to Resolve Constipation in Two Formula-Fed Infants. Annals of Nutrition and Metabolism, 2006; 50(4):368-371. http://dx.doi.org/10.1159/000094301

ŠINDELÁŘOVÁ, J. 1985. Obsah dusičnanov a dusitanov v zelenine. Bratislava Príroda. 1985, $64 \mathrm{~s}$.

TÖlGYESSY, J., HARANGOZÓ, M., DAXNEROVÁ, O. 2000. Monitoring životného prostredia. Univerzita Mateja Bela : Banská Bystrica 2000. $143 \mathrm{~s}$.

VALŠÍKOVÁ, M. 2005. Niekol'ko zásad správneho skladovania zeleniny. Záhradkár, 2005; 41(11):64. 